\title{
Intensitas Cacing Ektoparasit Ikan Kerapu Tikus Cromileptes altivelis pada Karamba Jaring Apung di Perairan Situbondo Jawa Timur
}

\author{
Gunanti Mahasri1*, Putri Desi Wulansari' dan Indah Hidayati Imani² \\ 'Departemen Manajemen Kesehatan Ikan dan Budidaya Perairan, Fakultas Perikanan dan \\ Kelautan Universitas Airlangga \\ Kampus C, Mullyorejo Surabaya 60115 \\ 2Program Studi Akuakultur, Fakultas Perikanan dan Kelautan Universitas Airlangga \\ Kampus C, Mulyorejo Surabaya 60115 \\ E-mail: mahasritot@gmail.com
}

\begin{abstract}
Helminth Ectoparasite Intensity of Humpback Grouper (Cromileptes Altivelis) in Floating Cage Net's In Situbondo Sea, East Java
\end{abstract}

This study aims to determine the intensity of ectoparasite helminth of Humpback Grouper (Cromileptes altivelis) in floating cage net's sea Situbondo. This research is a survey research using descriptive analysis to complete data of ectoparasites helminth of humpback grouper in floating cage net's Sea Situbondo. The humpback grouper use $8-10 \mathrm{~cm}$ and $13-20 \mathrm{~cm}$ in size taken from floating cage net's in Situbondo Sea, East Java. The samples use 30 fishes for each size based on a reference from floating cagenet's Situbondo, East Java. The results show that ectoparasite helmint which found at floating cage net's sea Situbondo namely Zeylanicobdella and Neobenedenia. The value of the intensity and degree of infestation of a single infestation of Zeylanicobdella at floating cage net is 4.7 individual/fish (low). In a single infestation Neobenedenia in floating net cage is 2.5 individual/fish (low). In the infestation of a mixture of Zeylanicobdella and Neobenedenia in floating net cage are 9.5 individual/fish (average).

Keywords: Helminth; ectoparasite; Intensity; infestation; humpback grouper

\begin{abstract}
Abstrak
Penelitian ini bertujuan untuk mengetahui intensitas cacing ektoparasit ikan kerapu tikus (Cromileptes altivelis) pada karamba jaring apung di perairan laut Situbondo. Penelitian ini merupakan penelitian survei dengan menggunakan analisis deskriptif untuk melengkapi data cacing ektoparasit ikan kerapu tikus pada karamba jaring apung (KJA). Ikan kerapu tikus yang digunakan adalah ukuran 8-10 cm dan $13-20 \mathrm{~cm}$ yang diambil dari KJA di perairan laut Situbondo. Sampel yang digunakan yaitu masing-masing 30 ekor untuk tiap ukuran dengan berdasar acuan. Hasil penelitian menunjukkan bahwa ditemukan cacing ektoparasit pada KJA di perairan laut Situbondo yaitu Zeylanicobdella dan Neobenedenia. Nilai intensitas dan derajat infestasi dari infestasi tunggal Zeylanicobdella pada ikan kerapu di Karamba Jaring Apung (KJA) adalah 4,7 individu/ekor(ringan). Pada infestasi tunggal Neobenedenia di KJA adalah 2,5 individu/ekor yang termasuk dalam infestasi ringan. Sedangkan pada infestasi campuran Zeylanicobdella dan Neobenedenia yang ditemukan adalah 9,5 individu/ekor yang termasuk dalam infestasi sedang. Hasil penelitian ini dapat digunakan sebagai acuan dalam pencegahan penyakit helminth pada budidaya ikan kerapu.
\end{abstract}

Kata kunci: Intensitas; infestasi; ektoparasit; kerapu; karamba

\section{PENDAHULUAN}

Ikan kerapu tikus (Cromileptes altivelis) merupakan ikan komoditas laut yang mengalami peningkatan aktivitas ekspor secara stabil selama kurun waktu 2018 mencapai rataan harian yaitu 605.132 ekor dalam data produksi kondisi hidup di seluruh 
wilayah Indonesia (BKIPM KKP, 2018). Berdasarkan tingginya permintaan pasar maka ikan kerapu tikus mulai di budidaya untuk menghindari kepunahan. Tingkat keberhasilan dari budidaya ikan kerapu tikus ditentukan oleh adanya benih yang berkualitas (BSN, 2011). Benih dengan ukuran lebih dari $10 \mathrm{~cm}$ akan mengalami masa transisi di karamba jaring apung (KJA) atau disebut dengan sistem pendederan.

Pembenihan kerapu tikus di KJA mengalami permasalahan salah satunya disebabkan oleh agen infeksius adalah cacing ektoparasit (Sumino, 2017). Intensitas adalah rata-rata jumlah parasit yang menginfestasi setiap ekor ikan (Kurniawan, 2015). Sedangkan menurut Kriswijayanti et al. (2019) derajat infestasi merupakan tingkat keparahan akibat kerusakan parasit terhadap inang. Faktor penting yang menentukan intensitas dan derajat infestasi adalah ukuran tubuh, pengaruh pergerakan, makanan, siklus dan kondisi pemeliharaan hidup inang (Kurniawan, 2015).

Salah satu kasus infestasi cacing ektoparasit yang telah ditemukan pada ikan kerapu tikus di KJA perairan Teluk Hurun, Lampung adalah cacing Benedenia intensitas 4,5 individu/ekor dengan derajat infestasi yaitu ringan. Selain itu juga ditemukan cacing Haliotrema intensitas 1 individu/ekor dengan derajat infestasi yaitu ringan serta cacing Pseudorhabdosynochus intensitas 4,5 individu/ekor dengan derajat infestasi yaitu ringan (Sumino et al., 2017). Subekti et al. (2012) menyatakan bahwa ditemukan Neobenedenia, Benedenia dan Pseudorhabdosynochus di KJA milik Unit Pengelolaan Budidaya Laut (UPBL) Situbondo serta ditambahkan oleh Mahardika et al. (2018) Zeylanicobdella arugamensis juga ditemukan sering menginfestasi ikan kerapu tikus di perairan Bali Utara.

Tujuan dari penelitian ini adalah (1) Mengetahui intensitas cacing ektoparasit yang menginfestasi ikan kerapu tikus di KJA perairan laut Situbondo; (2) Mengetahui derajat infestasi cacing ektoparasit yang menginfestasi benih kerapu tikus di KJA perairan laut Situbondo.

\section{MATERI DAN METODE}

Lokasi pengambilan sampel ikan kerapu tikus dilakukan di KJA perairan laut
Situbondo. Ukuran sampel ikan kerapu yang digunakan adalah $8-10 \mathrm{~cm}$ dan $13-20 \mathrm{~cm}$. Menurut Cameron (2002) bahwa banyaknya sampel yang diambil untuk penelitian survei adalah minimal 30 ekor tiap populasi telah mewakili data dalam satu wilayah. Berdasarkan hal tersebut maka pengambilan sampel benih kerapu tikus pada masingmasing ukuran adalah 30 ekor.

Pemeriksaan cacing ektoparasit pada benih kerapu tikus menggunakan metode natif. Pemeriksaan cacing ektoparasit meliputi bagian permukaan tubuh dan insang baik pada benih Ukuran $8-10 \mathrm{~cm}$ maupun 13-20 cm. Pemeriksaan ektoparasit cacing pada insang dilakukan langsung dibawah mikroskop perbesaran 40x dan 100x. Cacing ektoparasit pada ikan kerapu tikus yang nantinya ditemukan akan disimpan pada alkohol gliserin 5\% (Fidyandini et al., 2012).

Perhitungan intensitas dilakukan pada setiap spesies cacing ektoparasit setelah diketahui spesies yang menginfestasi setiap sampel benih kerapu tikus. Hal ini sesuai dengan pernyataan Kriswijayanti et al. (2019) menyatakan bahwa jumlah ektoparasit pada sampel yang positif terinfestasi dihitung tiap ekor. Rumus perhitungan intensitas dihitung menurut Barton and Richard (1996).

Kriswijayanti et al. (2019) menyatakan bahwa setelah jumlah ektoparasit pada sampel yang positif terinfestasi dihitung tiap ekor maka dilakukan pengelompokan sesuai derajat infestasi dari tiap ekor sampel ikan yang terinfestasi ektoparasit. Penentuan derajat infestasi ektoparasit menurut Williams and Williams (1996) disajikan dalam Tabel 1.

Analisis data yang digunakan pada penelitian ini yaitu menggunakan analisis deskriptif. Analisis deskriptif ini bertujuan untuk melengkapi data cacing ektoparasit ikan kerapu tikus pada karamba jaring apung (KJA).

\section{HASIL DAN PEMBAHASAN}

Hasil pemeriksaan cacing ektoparasit pada ikan kerapu tikus di KJA perairan laut Situbondo, menunjukkan bahwa ikan kerapu cantang yang diambil dari KJA di perairan laut Situbondo terinfestasi campuran oleh cacing Zeylanicobdella sp. dan cacing 
Tabel 1. Derajat infestasi cacing ektoparasit

\begin{tabular}{cc}
\hline Jumlah Cacing ektoparasit (individu/ekor) & Derajat infestasi \\
\hline 0 & Normal \\
$1-5$ & Ringan \\
$6-50$ & Sedang \\
$51-100$ & Berat \\
$>100$ & Sangat berat \\
$>1000$ & Super infeksi \\
\hline
\end{tabular}

Sumber: Williams dan Williams (1996)

Neobenedenia sp. intensitas sebanyak 147 individu per ekor. Gambar cacing yang ditemukan dapat dilihat pada Gambar 1 dan Gambar 2.

Hasil perhitungan intensitas dan penentuan derajat infestasi ikan kerapu tikus yang terinfestasi cacing ektoparasit di KJA perairan laut Situbondo dapat dilihat pada Tabel 3-5. Intensitas maupun derajat infestasi tertinggi terdapat pada infestasi campuran Zeylanicobdella dan Neobenedenia yang menginfestasi benih kerapu tikus KJA dengan intensitas 9,5 individu/ekor sehingga dikategorikan sedang. Hasil dari penentuan derajat infestasi cacing ektoparasit yang ditemukan dalam penelitian ditentukan berdasarkan hasil dari perhitungan intensitas kemudian dikategorikan menurut acuan dari Williams and Williams (1996). Jumlah semua cacing yang ditemukan pada 8 ekor ikan kerapu tikus yang terinfestasi campuran cacing Zeylanicobdella sp. adalah sebanyak 76 cacing dengan intensitas sebesar 9,5 individu per ekor dan termasuk dalam kategori infestasi SEDANG. Sedangkan yang terinfestasi tunggal oleh Zeylanicobdella sp. ditemukan 14 ekor ikan kerapu positif sebanyak 66 individu cacing dengan intensitas sebesar 4,7 dan termasuk dalam kategori RINGAN. Untuk ikan kerapu yang terinfestasi tunggal oleh Neobenedenia sp. yang positif hanya 2 ekor dengan jumlah cacing yang ditemukan terdapat 5 individu,dengan intensitas 2,5 individu yang termasuk kategori infestasi Ringan.

Pengukuran kualitas air dilakukan sebelum pengambilan sampel sehingga pengukuran kualitas air dilakukan sebanyak dua kali yaitu di hatchery UPBL Situbondo dan KJA BPBAP Situbondo. Parameter kualitas air yang diukur meliputi suhu, DO, pH, salinitas dan amonia. Pengukuran kualitas air dilakukan sebagai parameter pendukung pada penelitian dengan tujuan mengetahui kondisi lingkungan yang merupakan salah satu faktor stres. Hasil pengukuran kualitas air dapat dilihat pada Tabel 6.

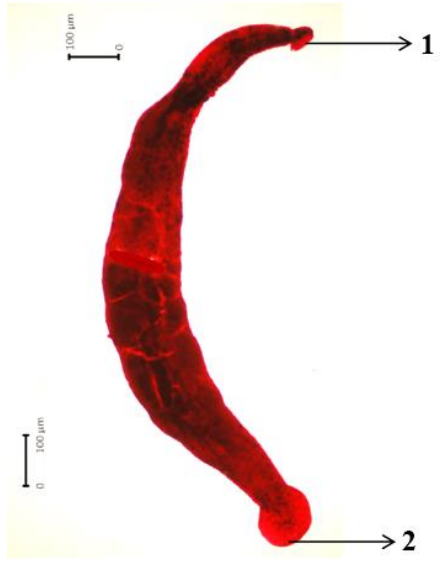

Gambar 1. Zeylanicobdella dengan perbesaran 40x. Keterangan: (1) anterior sucker, (2) posterior sucker

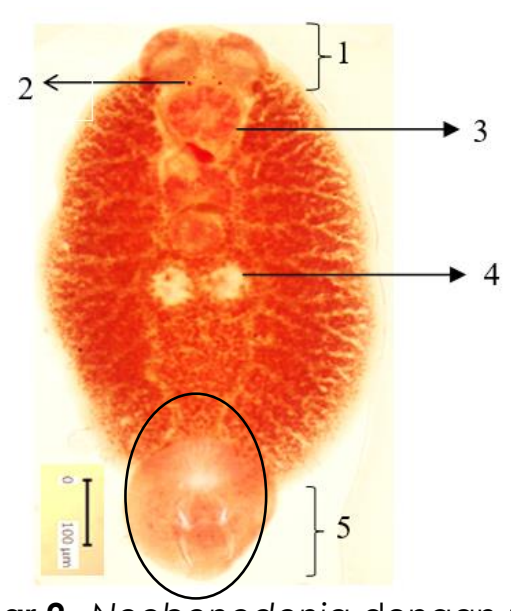

Gambar 2. Neobenedenia dengan perbesaran 100x. Keterangan: (1) adhesive organ, (2) eye spots, (3) pharynx, (4) testis, (5) ophisthaptor 
Cacing ektoparasit yang ditemukan menginfestasi ikan kerapu tikus di KJA perairan laut Situbondo dalam penelitian ini adalah Zeylanicobdella dan Neobenedenia. Zeylanicobdella sebagian besar ditemukan pada permukaan tubuh, mata, mulut, sirip ventral dan sirip dorsal. Hal ini sesuai dengan pernyataan Mahardika et al. (2018) bahwa lintah (Cacing) ini paling sering ditemukan pada mulut, sirip dorsal dan permukaan tubuh. Cacing ini dapat menyebabkan pembengkakan dan kemerahan pada kulit hingga sirip menjadi geripis. Neobenedenia sebagian besar ditemukan menginfestasi bagian mata dan permukaan tubuh kerapu tikus. Hal ini sesuai dengan penelitian Johnny et al. (2002) bahwa ditemukan Neobenedenia yang menginfestasi bagian mata ikan kerapu tikus di Balai Besar Riset Perikanan Budidaya Laut Gondol hingga menyebabkan kebutaan.

Berdasarkan hasil penelitian diketahui bahwa intensitas Zeylanicobdella dan Neobenedenia yang menginfestasi campuran kerapu tikus di KJA terdapat sebanyak 9,5 individu/ekor. Intensitas Zeylanicobdella yang menginfestasi tunggal kerapu tikus di KJA terdapat sebanyak 4,7 individu/ekor.

Intensitas Neobenedenia yang menginfestasi tunggal kerapu tikus di KJA terdapat sebanyak 2,5 individu/ekor. Hasil perhitungan dari intensitas digunakan untuk menentukan derajat infestasi cacing ektoparasit yang menginfestasi kerapu tikus baik di KJA.

Derajat infestasi Zeylanicobdella dan Neobenedenia yang menginfestasi campuran kerapu tikus di KJA dikategorikan sedang. Derajat infestasi Zeylanicobdella yang menginfestasi tunggalkerapu tikus di KJA dikategorikan ringan. Derajat infestasi Neobenedenia yang menginfestasi tunggal kerapu tikus di KJA dikategorikan ringan.

Menurut Cruz-Lacierda et al. (2002) bahwa faktor pendukung tingginya infestasi Zeylanicobdella antara lain turbiditas air yang masuk terlalu tinggi. Turbiditas air merupakan tingkat kekeruhan air yang biasanya disebabkan oleh materi tersuspensi. Faktor lain yang mendukung infestasi Zeylanicobdella adalah salinitas dan kondisi perairan. Zeylanicobdella baik stadia telur maupun dewasa mampu menetas dan hidup pada media pemeliharaan air laut hingga air payau atau dengan salinitas 5-30 ppt (Mahardika et al., 2018). Kondisi perairan yang tenang diketahui memberikan dampak pada siklus hidup Zeylanicobdella lebih panjang dalam mengalami pertumbuhan (Kua et al., 2010).

Neobenedenia pada KJA tergolong lebih tinggi. Menurut Novriadi et al. (2014) faktor pendukung adanya Neobenedenia adalah berkaitan dengan salinitas sebagai penunjang pertumbuhan yang berkisar antara 28-32 ppt. Neobenedenia juga mampu berkembang cepat apabila sanitasi perairan buruk akibat kadar oksigen rendah maupun amonia tinggi.

Berdasarkan hasil penelitian diketahui bahwa cacing ektoparasit lebih banyak ditemukan menginfestasi kerapu tikus di KJA. Hal ini karena beberapa faktor penting yang menentukan serangan parasit terhadap inang adalah ukuran tubuh inang, makanan inang dan tempat pemeliharaan (Kurniawan, 2015). Pada penelitian ini sampel yang digunakan adalah kerapu tikus berukuran 8$10 \mathrm{~cm}$ dan $13-20 \mathrm{~cm}$.

Pada tahap pembenihan ini sistem pertahanan tubuh dari inang masih belum sempurna sehingga rentan terhadap patogen (PAC, 2016). Menurut Noble and Noble (1989) bahwa semakin panjang ukuran tubuh inang maka semakin tinggi infestasi yang dibuat oleh parasit tertentu. Benih kerapu tikus di KJA memiliki ukuran yang lebih panjang sehingga luas penampang tubuh lebih luas dan berpotensi besar untuk terinfestasi cacing ektoparasit.

Pakan yang digunakan pada pembenihan kerapu tikus yaitu pakan ikan rucah untuk di KJA. Pakan ikan rucah yang diberikan pada kerapu tikus di KJA berpotensi sebagai pembawa penyakit. Hal ini karena ketersediaan dari pakan ikan rucah yang sulit terpenuhi secara konsisten dan tergantung dari hasil tangkapan. Pakan ikan rucah memiliki kualitas yang bervariasi sehingga mampu menjadi limbah buangan yang tinggi. Berdasarkan beberapa alasan ini maka pakan pelet dinilai lebih baik kualitasnya daripada pakan ikan rucah (Fauzi et al., 2008).

Tempat pemeliharaan termasuk salah satu faktor yang menentukan intenstas dan derajat infestasi cacing ektoparasit pada 
Tabel 6. Hasil pengukuran kualitas air di KJA perairan laut Situbondo

\begin{tabular}{cccccc}
\hline Pengambilan & Suhu $\left({ }^{\circ} \mathrm{C}\right)$ & $\mathrm{DO} \mathrm{mg} / \mathrm{L})$ & $\mathrm{pH}$ & Salinitas $(\mathrm{ppt})$ & Amonia $(\mathrm{mg} / \mathrm{L})$ \\
\hline KJA perairan laut & $30-31$ & $7-9$ & $7-8$ & $30-31$ & $3-5$ \\
Situbondo & $28-32$ & $>5$ & $7,5-8,5$ & $28-33$ & $\leq 0,01$ \\
BSN (2011) & & &
\end{tabular}

inang (Kurniawan, 2015). Kerapu tikus di KJA merupakan ikan yang sedang mengalami masa adaptasi dari sistem pembenihan tertutup di hatchery ke KJA. Pada masa ini benih rentan terhadap stres karena perubahan kondisi lingkungan dan sistem daya tahan tubuhnya belum sempurna. Sistem pendederan di KJA yang bergantung dengan kondisi alam menyebabkan sulit untuk terkontrol sehingga ikan liar dan air berpotensi masuk serta stres akibat arus perairan. Manajemen pengelolaan di KJA memungkinkan rendah akibat jarangnya pergantian jaring sehingga menjadi kotor dan mampu digunakan untuk tempat melekatnya telur cacing (Hadiroesyani et al., 2010).

Hasil pengukuran kualitas air pada saat pengambilan sampel relatif baik kecuali pada kadar amonia. Kadar amonia di KJA adalah 3-5 mg/L. Hal ini tidak sesuai dengan pernyataan BSN (2011) bahwa kadar amonia yang baik untuk pertumbuhan benih kerapu adalah $\leq 0,01 \mathrm{mg} / \mathrm{L}$. Amonia yang tinggi terutama di KJA akibat adanya pembusukan yang berasal dari pemberian pakan tidak sesuai dengan frekuensi maupun pakan ikan rucah. Kondisi dengan amonia tinggi mampu memicu munculnya cacing ektoparasit (Fauzi et al., 2008).

Kondisi di KJA adalah suhu $30-31^{\circ} \mathrm{C}$, DO 7-9 mg/L, pH 7-8 dan salinitas 30-31 ppt. Hal ini telah sesuai dengan pernyataan BSN (2011) bahwa kondisi perairan yang sesuai bagi benih kerapu tikus adalah dengan suhu 28-32 ${ }^{\circ} \mathrm{C}$, $\mathrm{pH}$ 7,5-8,5, salinitas 28-33 ppt, dan DO > $5 \mathrm{mg} / \mathrm{L}$ dan juga sesuiai dengan Mahasri dkk (2019).

\section{KESIMPULAN}

Berdasarkan hasil penelitian dapat disimpulkan bahwa cacing yang ditemukan pada ikan kerapu tikus (Cromileptes altivelis) pada Karamba Jaring Apung di Perairan Laut Situbondo adalah Zeylanicobdella dan Neobenedenia. Intensitas tertinggi terdapat pada cacing ektoparasit Zeylanicobdella dan Neobenedenia dengan intensitas 9,5 individu/ekor yang termasuk dalam kategori infestasi sedang.

\section{DAFTAR PUSTAKA}

Azwar, S. 2010. Metode Penelitian. Pustaka Pelajar. Yogyakarta. Hal. 83.

Badan Karantina Ikan Pengendalian Mutu dan Keamanan Hasil Perikanan, Kementerian Kelautan dan Perikanan. 2018. BKIPM Statistik: Volume Ekspor Produk Perikanan Hidup Ikan Kerapu Tahun 2018.2 Diakses: www.bkipm.kkp.go.id 11 November 2018.

Badan Standardisasi Nasional (BSN). 2011. Ikan Kerapu Bebek (Cromileptes altivelis, Valenciences) - Bagian 2: Benih. BSN 016487.2. Hal. 3-4.

Barton, D.P. \& Richard, S.J. 1996. Helminth Infracommunities in Litoria Genimaculata (Amphibia: Anura) from Birthday Creek, an Unpland Rainforest Stream in Northern Queensland, Australia. International Journal for Parasitology, 26(12):1381-1385.

Cameron, A. 2002. Survey Toolbox for Aquatic Animal Diseases. A Pratical Manual and Software Package. ACIAR Monograph. Australian Center for International Agricultural Research, pp. 70-75.

Cruz-Lacierda, E.R. \& Erazo-Pagador, G.E., 2004. Parasitic Diseases. Diseases of Culture Grouper, 4:43-45.

Fauzi, I.A., Mokoginta, I. \& Yaniharto, D. 2008. Pemeliharaan Ikan Kerapu Bebek (Cromileptes altivelis) yang Diberi Pakan Pelet dan Ikan Rucah di Keramba Jaring Apung. J. Akuakultur Ind.a, 7(1): 65-70.

Fidyandini, H.P., Subekti S. \& Kismiyati. 2012. Identifikasi dan Prevalensi Ektoparasit pada Ikan Bandeng (Chanos chanos) yang Dipelihara di Karamba Jaring Apung UPBL Situbondo dan di Tambak Desa Bangunrejo Kecamatan Sidoarjo. J. Mar.Coast. Sci., 1 (2): 91-112. 
Hadiroesyani, Y., Effendi, I., Rahayu, A.M. \& Arianty, H.S. 2010. Infestasi Parasit pada Benih Ikan Kerapu Macan (Epinephelus fuscoguttatus) di Karamba Jaring Apung Balai Sea Farming, Kepulauan Seribu Jakarta. J. Akuakultur Ind., 9(2):140-141.

Johnny, F., Roza, D. \& Prisdiminggo. 2002. Kejadian Penyakit Infeksi Parasit pada Ikan Kerapu di Karamba Jaring Apung Teluk Ekas, Kabupaten Lombok Timur, Nusa Tenggara Barat. Balai Besar Riset Perikanan Budidaya Laut Gondol, Bali dan Balai Pengkajian Teknologi Pertanian Nusa Tenggara Barat. Hal. 181-184.

Kriswijayanti, B.D., Kismiyati, K. \& Kusnoto, K., 2019. Identifikasi Dan Derajat Infestasi Lernaea Pada Ikan Maskoki (Carassius auratus) Di Kabupaten Tulungagung, Jawa Timur. J. Aquacul. Fish Health, 3(1):1-7.

Kua, B.C., Azmi, M.A. \& Hamid, N.K.A. 2010. Life Cycle of the Marine Leech (Zeylanicobdella arugamensis)Isolated from Sea Bass (Lates calcarifer) Under Laboratory Conditions. Aquaculture. Departement of Fisheries Malaysian. Penang, Malaysia. pp. 154-156.

Kurniawan, A. 2015. Prevalensi, Intensitas dan Identifikasi Molekuler Ektoparasit pada Kerapu di Keramba Jaring Apung Teluk Pegametan Kabupaten Buleleng. Jurusan Perikanan Fakultas Pertanian Universitas Gadjah Mada. Yogyakarta. Hal. 59.

Mahardika, K.I., Mastuti, \& Zafran. 2018. Respon Lintah Laut (Zeylanicobdella arugamensis) Terhadap Salinitas Berbeda Secara Laboratorium. Jurnal Penelitian Perikanan dan Kelautan, 2(3):208-214. doi: 10.21776/ub.jfmr.2018.002.03.9
Mahasri, G., Sulmatiwi, L., Sudarno, Prayogo, Pamenang, G.D. \& Harifa, A.I., 2019, Nanobubble Aquaculture System: Its Effect Towards Immune Response and Infection of Vibrio sp. in Vannamei Shrimp (Litopenaeus vannamei). Indian Vet. J., 96(05):21-23

Noble, G.A. \& Noble, E.R. 1989. Parasitologi: Biologi Parasit Hewan. Terjemahan: Wardiarto. Gadjah Mada University Press.Yogyakarta. Hal 3-44.

Novriadi, R., Agustina, S.S., Bahri, S., Sunantara, D. \& Wijayanti, E. 2014. Distribusi Patogen dan Kualitas Lingkungan pada Budidaya Perikanan Laut di Provinsi Kepulauan Riau. Depik. 3(1):83-90.

Palawan Aquaculture Corporation (PAC). 2016. Humpback Grouper (Cromileptes altivelis). www.palawanaqua.ph 14 November 2018.

Subekti, S., Kusdarwati, R., \& Wiyatno, F.H. 2012. Identifikasi dan Prevalensi Ektoparasit pada Ikan Kerapu Tikus (Cromileptes altivelis) di Karamba Jaring Apung Unit Pengelola Budidaya Laut Situbondo Jurnal Ilmiah Perikanan dan Kelautan, 4(1):103-108.

Sumino, C.T., Anggraeni \& Tardiono. 2017. Inventarisasi, Prevalensi dan Intensitas Ektoparasit Pada Ikan Kerapu (Epinephelus sp.) di Keramba Jaring Apung Perairan Teluk Hurun Lampung. Jurnal Perikanan dan Kelautan, 7(1): 1-7.

Williams, E. H \& L. B. Williams. 1996. Parasites of Offishore Big Game Fishes of Puerto Rico and The Western Atlantic. Antillean College Press. Mayaguez. 